\title{
Two new species of Coccidohystrix Lindinger (Hemiptera: Coccomorpha: Pseudococcidae) with notes on the related genus Artemicoccus Balachowsky
}

Coccidohystrix Lindinger (Hemiptera: Coccomorpha: Pseudococcidae) cinsine ait iki türün tanımlanması ve Artemicoccus cinsi üzerine sistematik araştırmalar

M. Bora KAYDAN ${ }^{1}$
Giuseppina PELLIZZARI ${ }^{2}$

\section{Éva SZITA ${ }^{3 *}$}

\begin{abstract}
Summary
Scale insect (Hemiptera: Coccomorpha: Pseudococcidae) samples were collected in Turkey (HakkariYüksekova) and Bulgaria (Kresna Gorge) between 2007 and 2012. Two new Coccidohystrix Lindinger species, are described and illustrated. An identification key including the new species is also provided. Additionaly, the type material of $C$. zangherii was studied and the species is transferred into the genus Artemicoccus Balachowsky. A new identification key for species in the genus Artemicoccus is also provided.
\end{abstract}

Keywords: Phenacoccinae, lacking ostiole. Eriococcidae

\section{Özet}

Bu çalışmada 2007 ve 2012 yıllarında Türkiye (Hakkari-Yüksekova) ve Bulgaristan (Kresna Gorge)'dan toplanan unlubit (Hemiptera: Coccomorpha: Pseudococcidae) örnekleri incelenmiştir. Çalışma sonucunda Coccidohystrix Lindinger cinsine ait iki yeni tür tanımlanmış olup cinse ait yeni teşhis anahtarı oluşturulmuştur. Buna ek olarak C. zangherii Kozár \& Pellizzari' nin tip materyalleri incelenerek Artemicoccus Balachowsky cinsine aktarılmış ve Artemicoccus cinsine ait yeni teşhis anahtarı oluşturulmuştur.

Anahtar sözcükler: Phenacoccinae, ostiole eksikliği, Eriococcidae

${ }^{1}$ Çukurova University, Imamoglu Vocational School, Adana, Turkey

${ }^{2}$ Department of Agronomy, Food, Natural Resources, Animals and Environment DAFNAE, University of Padova, Italy,

${ }^{3}$ Plant Protection Institute, Centre for Agricultural Research, Hungarian Academy of Sciences, H-1022, Herman Ottó út 15,

Budapest, Hungary

* Sorumlu yazar (Corresponding author) e-mail: szita.eva@agrar.mta.hu

Alınış (Received): 17.07.2015 Kabul ediliş (Accepted): 04.12.2015 


\section{Introduction}

More intensive collecting and the identification of new scale insect species can help to improve the knowledge on morphological features of these insects and often allow to clarify the systematic position of controversial taxa.

In recent years the genera Artemicoccus and Coccidohystrix have been in the scope of several papers in which the above reported taxa are considered as separate genera (Danzig et al., 2012) or as synonyms (Gavrilov-Zimin \& Matile-Ferrero, 2014; Danzig \& Gavrilov-Zimin, 2014).

Within the Phenacoccinae (Hemiptera: Pseudococcidae), five genera include species with dorsal cerarii, namely Artemicoccus Balachowsky (2 species), Coccidohystrix Lindinger (9 species), Pedronia Green (4 species), Pedrococcus Mamet (8 species) and Synacanthococcus Morrison (3 species) (BenDov et al., 2015). The genus Peliococcus Borchsenius has also dorsal cerarii but the cerarian setae are narrowly conical setae whereas those of the five genera reported above are broadly conical (Williams, 2004). On the other hand in the genera Artemicoccus and Coccidohystrix both anterior and posterior ostioles are missing, while at least posterior ostioles occur in the other genera mentioned above. Artemicoccus and Coccidohystrix are considered as Palaearctic originated genera, Pedronia, Pedrococcus and Synacanthococcus are mainly from Oriental and Afrotropical regions (Williams, 2004).

The genus Artemicoccus was separated from the genus Centrococcus Borchsenius, (currently synonym of Coccidohystrix Lindinger) by Balachowsky (1953b) and includes two species: C. bispinus Borchsenius and C. lubersaci Balachowsky. Balachowsky (1953b) clarified the morphological differences between the two genera and added some important biological observation "in Artemicoccus the adult females were enclosed in a felt eggsac, in Coccidohistryx the adult females were mobile and covered with powdery wax". Moreover he considered that these mealybugs showed an affinity with Eriococcidae (Balachowsky 1953a, b).

Later Kozár \& Pellizzari (1989) described the new species C. zangherii Kozár \& Pellizzari in Coccidohystrix but admitted that it could be placed into the genus Artemicoccus; at that time they considered that the characters reported by Balachoswky were not sufficient to separate Artemicoccus from Coccidohystrix and concluded that a revision of these genera could led to the synonymy of Artemicoccus with Coccidohystrix.

Danzig et al. (2012) considered these two genera separately following Balachowsky (1953b) and Ben-Dov (1994) and provided a key for their differentiation. The main diagnostic morphological character between the two genera is the situation of dorsal conical setae: in Coccidohystrix the dorsal conical setae on dorsum are situated on elevated sclerotised prominences, while in Artemicoccus those are not on sclerotised prominences.

Gavrilov-Zimin \& Matile-Ferrero (2014) regarded Artemicoccus a subjective synonym of Coccidohystrix and described further two new species, C. maghribensis Gavrilov-Zimin \& Matile-Ferrero and C. monicae Gavrilov-Zimin \& Matile-Ferrero. Moreover they transferred Amonosterium echinatus (Balachowsky) to the genus Coccidohystrix as Coccidohystrix echinata (Balachowsky) comb. nov.

Danzig \& Gavrilov-Zimin (2014) considered Artemicoccus as a junior synonym of Coccidohystrix in their recent valuable volume on Pseudococcidae and indicated that the genus Coccidohystrix was very close to the family Eriococcidae.

Nine Coccidohystrix sensu stricto species are currently recognized (Ben-Dov et al., 2015); of which seven have a Palaearctic distribution (C. artemisiae (Kiritchenko), C. burumandi Moghaddam, C. echinata (Balachowsky), C. insolita (Green), C. samui Kozár \& Konczné Benedicty, C. splendens (Goux), C. zangherii Kozár \& Pellizzari Scaltriti), one is an Oriental species (C. eleusines Williams) and one an Afrotropical species (C. madecassa (Mamet)) (Ben-Dov et al., 2015) . 
The collecting of two new species referred to Artemicoccus -Coccidohystrix gave us the opportunity to reconsider the morphology of these two controversial taxa, also on the basis of a recent phylogenetical study that resulted these two genera as separate ones in a very distinct clade (Kaydan et al., 2015)

In the present study the authors agree with Balachowsky (1953b), Ben-Dov (1994), Danzig et al. (2012) and regard Coccidohystrix and Artemicoccus as separate genera and described two new Coccidohystrix species, collected in Turkey and Bulgaria with new identification key of the genus. In addition the type material of $C$. zangherii was studied and the species transferred to the genus Artemicoccus. A new identification key for the genus Artemicoccus is also provided.

\section{Materials and methods}

Scale insect samples were collected in Turkey (Hakkari-Yüksekova) and Bulgaria (Kresna Gorge) between 2007 and 2012. Specimens were taken from wild plants in natural areas. Collecting data, province, locality, GIS coordinates, date of collection, collector, data of the host plant and the collection numbers are given.

Specimens were slide-mounted for light microscopy using the method of Kosztarab \& Kozár (1988). Morphological terminology follows that of Kosztarab \& Kozár (1988) and Williams (2004) for description of the new mealybug species. Measurements and counts of the new species were taken from all available material.

All type materials are deposited in the Scale Insect Collection of Plant Protection Institute, Centre for Agricultural Research, Hungarian Academy of Sciences, Budapest, Hungary (PPI).

\section{Results}

\section{Genus Coccidohystrix Lindinger}

Echinococcus Balachowsky, 1936. Type species: Echinococcus echinatus Balachowsky, by original designation. Homonym of Echinococcus Rudolphi, 1801, in Vermes.

Coccidohystrix Lindinger, 1943. Replacement name for Echinococcus Balachowsky.

Centrococcus Borchsenius, 1948. Unjustified replacement name for Echinococcus; discovered by Morrison \& Morrison, 1966. Notes: Synonymy by community of type species.

Seabrina Neves, 1943: type species Seabrina cistorum Neves, 1943, by original designation and monotypy (synonymyzed by Danzig \& Gavrilov-Zimin, 2014).

Type species: Echinococcus echinatus Balachowsky, by original designation

Generic diagnosis. Adult female. Female covered with white powdery wax or with few threads of wax (Balachowsky, 1953b; Marotta \& Tranfaglia, 1994). Labium three segmented, slightly longer than wide. Posterior pair of spiracles always larger than anterior spiracles, spiracles associated with trilocular pores at opening of the atrium. Circulus absent. Legs well developed, claw with a denticle; tarsal digitules hair-like, not capitate; claw digitules knobbed, claw digitules broader than tarsal digitules. Both pairs of ostioles absent (except $C$. insolita, see comments). Anal lobes well developed. Anal ring oval, with 6 setae; with 1 inner row of pores and 1 or 2 outer rows of pores.

Dorsum. Antennae 7-9 segmented. Eyes oval, on a small basal cone. Number of cerari on margin varies between 16-18 pairs, each cerarius situated on an elevated sclerotised prominence bearing several (1-12) enlarged conical setae, several minute discoidal pores and 1 or 2 spine-like setae. These prominences form several rows along the body; the number of conical setae varies in different species. Dorsal body setae of various sizes (in C. artemisiae, C. burumandi, C. eleusines and C. insolita) or absent. Multilocular disc pores absent. Oral collar tubular ducts of one or two sizes or absent. Trilocular pores each 3-5 $\mu \mathrm{m}$ in diameter, often slightly larger than ventral trilocular pores, scattered over dorsum. Minute discoidal pores scattered. 
Venter. Most ventral setae slender and hair-like, of various sizes. Oral collar tubular ducts of one or two sizes present around vulva or in transverse rows on body segments. Multilocular disc pores present on posterior abdominal segments, especially around vulva, sometimes also on thorax and head. Quinquelocular pores absent or present around median area of thorax or scattered on venter. Trilocular pores present, mostly near spiracles, each $2.5-5.0 \mu \mathrm{m}$ in diameter. Minute discoidal pores scattered.

Comments. The genus Coccidohystrix can be distinguished by combination of the following characters (i) 7-9 segmented antennae; (ii) cerarii numbering 16-18 pairs, present on body margin, each cerarius formed of an elevated sclerotized prominence bearing several (1-12) enlarged conical setae, several minute discoidal pores and 1 or 2 spine-like setae, (iii) similar prominences distributed in longitudinal rows on dorsum, medial ones not divided; (iv) prominences and cerarii do not bear any trilocular pores (except in case of some population of C. artemisiae (Danzig et al., 2012).

The type material of $C$. zangherii was examined and consequently it was decided to transfer this species to the genus Artemicoccus as A. zangherii (Kozár \& Pellizzari) comb. nov. Moreover, according to the drawings and descriptions of C. echinata, C. maghribiensis Gavrilov-Zimin \& Matile-Ferrero and C. monicae Gavrilov-Zimin \& Matile-Ferrero by Gavrilov-Zimin \& Matile-Ferrero (2014) we regard these species as belonging to the genus Artemicoccus as A. echinatus (Balachowsky) comb. nov., A. maghribiensis (Gavrilov-Zimin \& Matile-Ferrero) comb. nov. and A. monicae (Gavrilov-Zimin \& MatileFerrero) comb. nov.

\section{Key to Palaearctic species of Coccidohystrix, adult females.}

1 - Oral collar tubular ducts present on dorsum. C. artemisiae (Kiritchenko)

- Oral collar tubular ducts absent on dorsum 2

2 - Oral collar tubular ducts on venter very few, if present, only on posterior abdominal segment .... 3

- Oral collar tubular ducts on venter numerous C. insolita (Green)

3 - Hind tibia with translucent pores 4

- Hind tibia without translucent pores. 6

4 - Antennae 9 segmented; ventral quinquelocular pores scattered. 5

- Antennae 7 segmented; ventral quinquelocular pores only on the posterior abdominal segment and near spiracles

C. zsuzsannae Kaydan sp. nov.

5 - Ventral trilocular pores present only on body submargin, with a few around spiracles

C. katiae Kaydan \& Szita sp. nov.

- Ventral trilocular pores scattered on body surface, numerous around spiracles

C. burumandi Moghaddam

6 - Elevated sclerotised prominence on dorsum without small spine like setae; dorsal prominences in 67 rows, number of enlarged conical setae on dorsal cerarii maximum 8

C. splendens (Goux)

- Elevated sclerotised prominence on dorsum with small spine like setae; dorsal plates in 5 rows, number of enlarged conical setae on dorsal prominences maximum 5

C. samui Kozár \& Konczné Benedicty 
Coccidohystrix zsuzsannae Kaydan, sp. nov. (Fig. 1).

Material studied. Holotype. Female, Turkey, Hakkari-Yüksekove road, N: 3740.966'; E: 044 06.227'; 1860 m; on plant from Asteraceae, 05.vii.2007, coll: M. Bora Kaydan, (KPCT: 3972).

Description. Adult female. Body elongate oval, $2.02 \mathrm{~mm}$ long, $1.32 \mathrm{~mm}$ wide. Eye marginal, 50-65 $\mu \mathrm{m}$ wide. Antenna 7 segmented, $400 \mu \mathrm{m}$ long; apical segment $65 \mu \mathrm{m}$ long, $20 \mu \mathrm{m}$ wide, with apical setae $17.5 \mu \mathrm{m}$ long plus three fleshy setae, each $20 \mu \mathrm{m}$ long. Tentorium $170 \mu \mathrm{m}$ long, $160 \mu \mathrm{m}$ wide. Labium $140 \mu \mathrm{m}$ long, $87.5 \mu \mathrm{m}$ wide. Anterior spiracles $60 \mu \mathrm{m}$ long, $25 \mu \mathrm{m}$ wide across atrium; posterior spiracles $65 \mu \mathrm{m}$ long, $25 \mu \mathrm{m}$ wide across atrium. Legs well developed; data for first legs: coxa $145 \mu \mathrm{m}$, trochanter + femur $260 \mu \mathrm{m}$, tibia + tarsus $325 \mu \mathrm{m}$, claw $30 \mu \mathrm{m}$, tarsal digitules each $20 \mu \mathrm{m}$ long, hair-like, claw digitules knobbed each $27.5 \mu \mathrm{m}$ long; data for mid legs: coxa $130 \mu \mathrm{m}$, trochanter + femur $275 \mu \mathrm{m}$, tibia + tarsus $335 \mu \mathrm{m}$, claw $27.5 \mu \mathrm{m}$, tarsal digitules each $20 \mu \mathrm{m}$ long, hair-like, claw digitules knobbed each $27.5 \mu \mathrm{m}$ long; data for hind legs: coxa $140 \mu \mathrm{m}$, trochanter + femur $280 \mu \mathrm{m}$, tibia + tarsus $360 \mu \mathrm{m}$, claw 30 $\mu \mathrm{m}$, tarsal digitules each $20 \mu \mathrm{m}$ long, hair-like, claw digitules knobbed each $32.5 \mu \mathrm{m}$ long. Anal ring 70 $\mu \mathrm{m}$ wide, with 6 setae, each setae 125-130 $\mu \mathrm{m}$ long. Cerarii 16 pairs, each cerarius formed of an elevated sclerotized prominence bearing several (5-8) enlarged conical setae, 3-6 minute discoidal pores and 1 or 2 spine-like setae each $4-5 \mu \mathrm{m}$ long.

Dorsum.Enlarged conical setae, each $27-45 \mu \mathrm{m}$ long on an elevated sclerotized prominence bearing 1-7 setae, 1-5 minute discoidal pores and 1-3 spine like setae. These prominences form five longitudinal rows along the body. Trilocular pores each $4-5 \mu \mathrm{m}$ in diameter, a few on the surface; minute discoidal pores each 2-3 $\mu \mathrm{m}$ diameter, scattered. Multilocular disc pores, quinquelocular pores and oral collar tubular ducts absent.

Venter. Body setae hair-like setae, each 15.0-50.0 $\mu \mathrm{m}$ long, longest setae medially on head. Apical setae of anal lobe each $70 \mu \mathrm{m}$ long. Multilocular disc pores absent, numbering of quinquelocular pores in rows on abdominal segments VIII + IX: 6; each pore $5 \mu \mathrm{m}$ in diameter in pentagonal shape. Trilocular pores, each 3-4 $\mu \mathrm{m}$ in diameter, present on the submargin, numerous near spiracles, each spiracles with 61-75 associated trilocular pores. Minute discoidal pores scattered, each 2-3 $\mu \mathrm{m}$ in diameter. Oral collar tubular ducts concentrated on abdominal segments: V 2, VI 4, VII 4.

Comments. C. zsuzsannae sp. nov. can be distiguished from other Coccidohystrix species in having (i) antennae seven segmented (ii) oral collar tubular ducts concentrated on abdominal segments: $\mathrm{V}, \mathrm{VI}, \mathrm{VII}$, (iii) a few quinquelocular pores only on abdominal segment VIII+IX; and (iv) a few trilocular pores sparse on dorsum and on ventral submargin. This species is very close to $C$. splendens (Goux) and C. burumandi Moghaddam, but differs from these two species in having seven-segmented antennae and much less quinquelocular pores on venter.

Etymology. This species is named after Zsuzsanna Konczné Benedicty (Plant Protection Institute, Centre for Agricultural Research, Hungarian Academy of Sciences, Budapest, Hungary) who made great studies on the scale insects.

Host plant. Asteraceae.

Distribution. Turkey. 


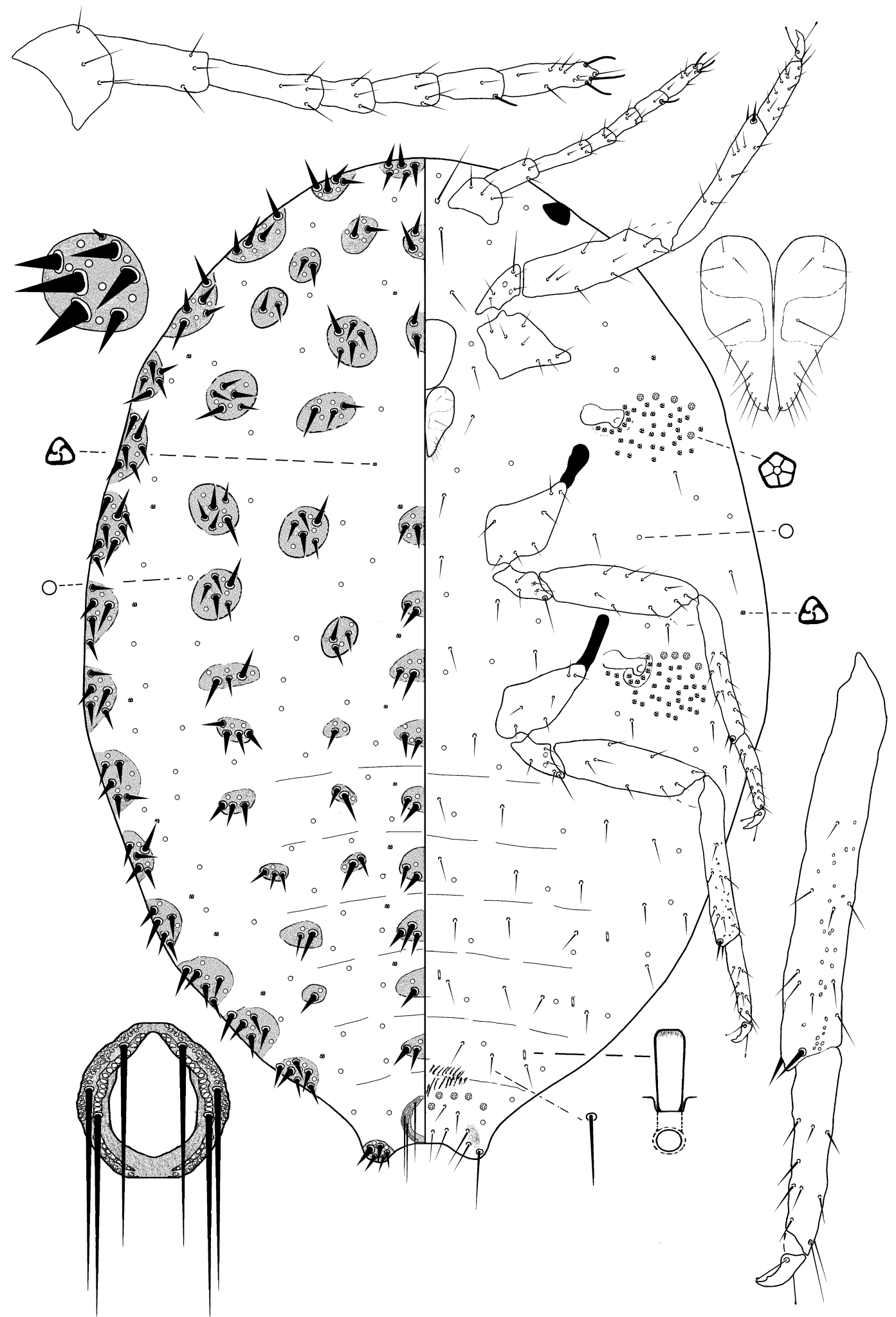

Figure 1. Coccidohystrix zsuzsannae Kaydan, sp. nov., holotype female. 
Coccidohystrix katiae Kaydan \& Szita, sp. nov. (Fig. 2).

Material studied. Holotype. Female, Bulgaria, Kresna Gorge, Thymus sp. (Lamiaceae), 27.vi.2012, coll: K. Fetykó (PPI: 10517).

Description. Adult female. Body elongate oval, $1.66 \mathrm{~mm}$ long, $1.09 \mathrm{~mm}$ wide. Eye marginal, $45-50$ $\mu \mathrm{m}$ wide. Antenna 9 segmented, $400 \mu \mathrm{m}$ long; apical segment 55-60 $\mu \mathrm{m}$ long, $20.0 \mu \mathrm{m}$ wide, with apical setae $15 \mu \mathrm{m}$ long plus three fleshy setae, each 20.0-22.5 $\mu \mathrm{m}$ long. Tentorium $140 \mu \mathrm{m}$ long, $125 \mu \mathrm{m}$ wide. Labium $107.5 \mu \mathrm{m}$ long, $95 \mu \mathrm{m}$ wide. Anterior spiracles 55-60 $\mu \mathrm{m}$ long, $25 \mu \mathrm{m}$ wide across atrium; posterior spiracles $62.5-65 \mu \mathrm{m}$ long, $25.0-27.5 \mu \mathrm{m}$ wide across atrium. Legs well developed; data for first

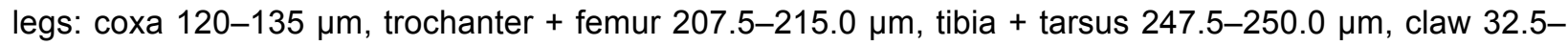
$35.0 \mu \mathrm{m}$, tarsal digitules each $22.5 \mu \mathrm{m}$ long, hair-like, claw digitules knobbed each $25 \mu \mathrm{m}$ long; data for mid legs: coxa $125 \mu \mathrm{m}$, trochanter + femur $215 \mu \mathrm{m}$, tibia + tarsus 255-260 $\mu \mathrm{m}$, claw $30 \mu \mathrm{m}$, tarsal digitules each 20.0-22.5 $\mu \mathrm{m}$ long, hair-like, claw digitules knobbed each $25 \mu \mathrm{m}$ long; data for hind legs: coxa $130 \mu \mathrm{m}$, trochanter + femur $220 \mu \mathrm{m}$, tibia+tarsus 292.5-300.0 $\mu \mathrm{m}$, claw 27.5-32.5 $\mu \mathrm{m}$, tarsal digitules each $25 \mu \mathrm{m}$ long, hair-like, claw digitules knobbed each 20.0-22.5 $\mu \mathrm{m}$ long. Anal ring $70 \mu \mathrm{m}$ wide, with 6 setae, each setae $110 \mu \mathrm{m}$ long. Cerarii 17 pairs, each cerarius formed of an elevated sclerotized prominence bearing several (2-7) enlarged conical setae, $2-5$ minute discoidal pores and 1 or 2 spine-like setae each $4-5 \mu \mathrm{m}$ long.

Dorsum. Body setae enlarged, each 15-25 $\mu \mathrm{m}$ long on an elevated sclerotized prominence bearing 1-7 setae, 1-5 minute discoidal pores and 1-3 spine like setae. Trilocular pores each 3-4 $\mu \mathrm{m}$ in diameter, a few on the surface, minute discoidal pores each 2-3 $\mu \mathrm{m}$ diameter, scattered on dorsum. Multilocular disc pores, quinquelocular pores and oral collar tubular ducts absent.

Venter. Body setae hair-like slender setae, each 7.5-45.0 $\mu \mathrm{m}$ long, longest setae medially on head. Apical setae of anal lobe each $100 \mu \mathrm{m}$ long. Multilocular disc pores absent, quinquelocular pores scattered on all surface, each pore 5-6 $\mu \mathrm{m}$ in diameter in pentagonal shape. Trilocular pores, each 3-4 $\mu \mathrm{m}$ in diameter, present on the submargin and associated to spiracles. Minute discoidal pores scattered over entire body, each 2-3 $\mu \mathrm{m}$ in diameter. Oral collar tubular ducts concentrated on abdominal segments VI 4, VII 2.

Comments. C. katiae can be distiguished from other Coccidohystrix species by (i) antennae nine segmented (ii) oral collar tubular ducts placed only anterior segments of vulva, (iii) quinquelocular pores scattered on venter; (iv) trilocular pores scattered on both venter and dorsum. This species is very close to $C$. samui Kozár \& Konczné Benedicty but differs from this species in having translucent pores on tibia, (absent on C. samui).

Etymology. This species is named after Katia Trencheva (University of Forestry, Faculty of Agronomy, Plant Protection Department, Sofia, Bulgaria) who made great studies on the scale insects in Bulgaria.

Host plant. Thymus sp. (Lamiaceae).

Distribution. Bulgaria 


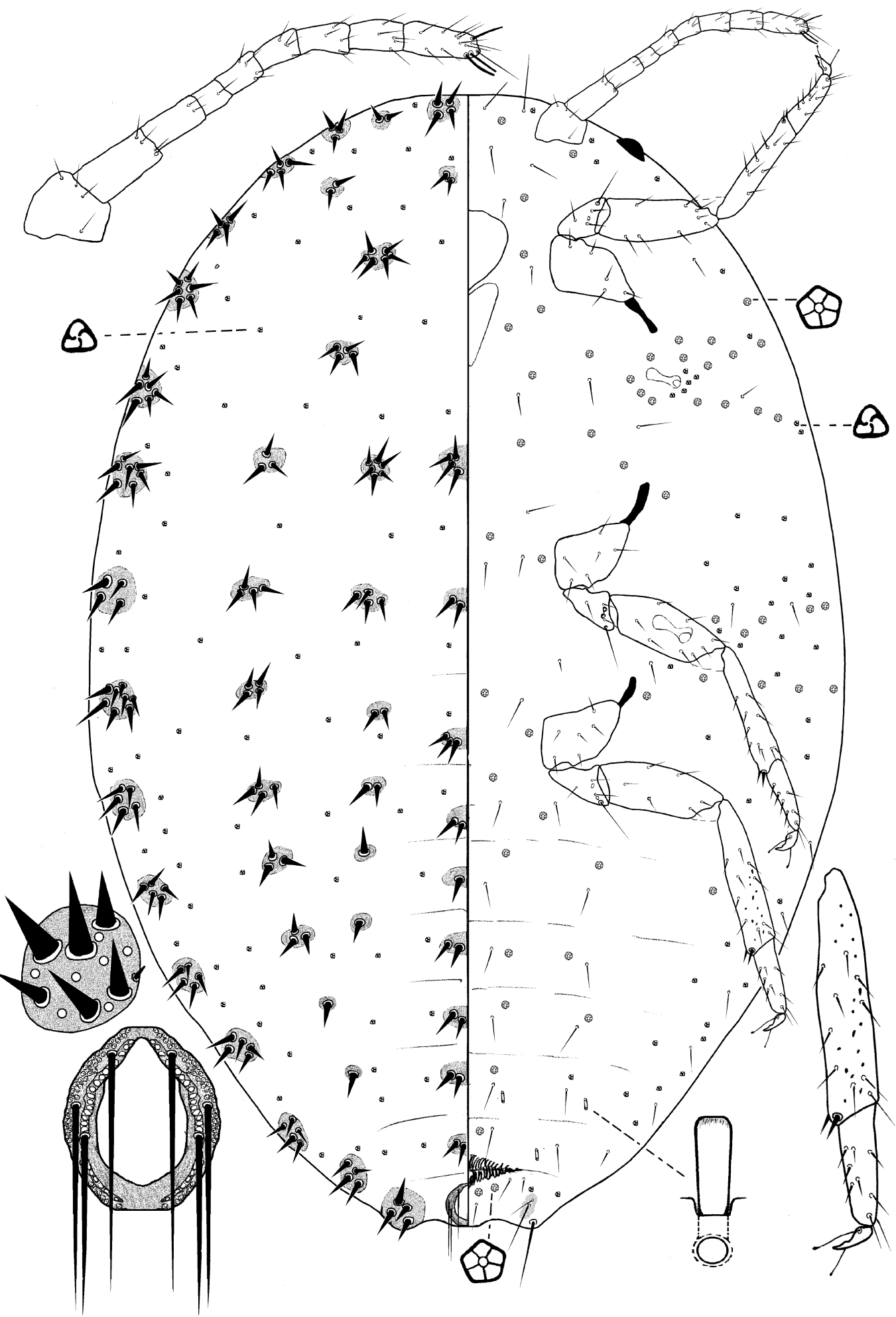

Figure 2. Coccidohystrix katiae Kaydan \& Szita, sp. nov., holotype female. 


\section{Genus Artemicoccus Balachowsky}

Artemicoccus Balachowsky, 1953b: 146.

Type species: Centrococcus bispinus Borchsenius, 1949, by original designation.

Generic diagnosis. Adult female.

Body oval, yellowish, enclosed in a felt-like eggsac, similar to that of Eriococcidae. Labium three segmented, slightly longer than wide. Posterior pair of spiracles always larger than anterior spiracles, spiracles associated with trilocular pores at opening of the atrium. Circulus absent. Legs well developed, claw with a denticle; tarsal digitules hair-like, not capitate; claw digitules knobbed, claw digitules broader than tarsal digitules. Both pairs of ostioles absent. Anal lobes well developed. Anal ring oval, with 1 inner row of pores and 1 or 2 outer rows of pores plus with 6 setae.

Dorsum. Antennae 7 segmented. Eyes oval, on a small basal cone. Number of cerarii variable: $7-$ 18 pairs present on body margin, each cerarius formed by 1-7 enlarged conical setae. Conical setae, similar to those of cerarii, singular or in groups of 2-5 also present on dorsum. Other dorsal body setae small cylindrical of various sizes. Multilocular disc pores absent. Oral collar tubular ducts of one or two sizes or absent. Trilocular pores each 3-5 $\mu \mathrm{m}$ in diameter, often slightly larger than ventral trilocular pores, scattered over dorsum. Minute discoidal pores scattered.

Venter. Most ventral setae slender and hair-like, of various sizes. Oral collar tubular ducts of one or two sizes present around vulva or in transverse rows on body segments. Multilocular disc pores present on posterior abdominal segments, especially around vulva, sometimes also on thorax and head. Quinquelocular pores absent or present around median area of thorax or scattered over surface. Trilocular pores each 2.5-5.0 $\mu \mathrm{m}$ in diameter, scattered over surface. Minute discoidal pores scattered.

After the detailed studies of Danzig et al. (2012) the borders between the genera Artemicoccus and Coccidohystrix become clearer, in having different combination of characters (characters for the genus Coccidohystrix in brackets): (i) enlarged conical setae situated on dorsum, not on elevated sclerotized plate (present on elevated sclerotized plate); (ii) dorsal spine-like setae (besides from conical enlarged setae) of different sizes (same size); (iii) anal lobes with three conical setae (more than three conical setae).

Artemicoccus zangherii (Kozár \& Pellizzari), comb. nova (Figure 3)

Coccidohystrix zangherii Kozár \& Pellizzari, 1989: 507. Holotype, female, ITALY: Campo Imperatore, Fonte Vetica, on Juniperus nana (deposited in DAFNAE). Paratype, female, same data as holotype.

Description: For detailes see (Kozár \& Pellizzari) 1989.

Comments. It was mentioned by the authors in the original description that this species could have been placed into the genus Artemicoccus (Kozár \& Pellizzari, 1989). They considered that Artemicoccus could be a possible synonym of Coccidohystrix but did not formally synonymized the two genera and described the new species in Coccidohystrix. 
Two new species of Coccidohystrix Lindinger (Hemiptera: Coccomorpha: Pseudococcidae) with notes on the related genus Artemicoccus Balachowsky

The type material of $C$. zangherii was examined and consequently, according to the genus concept reported above, this Juniperus feeding species is transferred from Coccidohystrix to Artemicoccus as $A$. zangherii (Kozár \& Pellizzari) comb. nov.

Moreover, according to the drawings and descriptions of C. echinata (Balachowsky, 1930), C. maghribiensis Gavrilov-Zimin \& Matile-Ferrero and C. monicae Gavrilov-Zimin \& Matile-Ferrero we regard the above reported species as belonging to the genus Artemicoccus as $A$. echinatus (Balachowsky) comb. nov., A. maghribiensis (Gavrilov-Zimin \& Matile-Ferrero) comb. nov. and A. monicae (GavrilovZimin \& Matile-Ferrero) comb. nov.

\section{Key to Artemicoccus species, adult female.}

1 - Dorsal oral collar tubular ducts numerous

- Dorsal oral collar tubular ducts very few or absent A. lubersaci (Balachowsky)

2 - Trilocular pores scattered on both venter and dorsum 3

- Trilocular pores present only on venter, near spiracles .............................................................. 5

3 - Groups of conical setae forming transverse rows on dorsum .................................................. 4

- Groups of conical setae only on body margin; rarely a few conical setae placed on dorsum

A. echinatus (Balachowsky)

4 - Dorsal oral collar tubular ducts of two sizes; conical enlarged dorsal setae up to seven for each setae group A. zangherii (Kozár \& Pellizzari)

- Dorsal oral collar tubular ducts of only one size; conical enlarged dorsal setae up to three for each setae group A. bispinus (Borchsenius)

5 - Groups of conical setae forming transverse rows on dorsum.

A. maghribiensis Gavrilov-Zimin \& Matile-Ferrero

- Groups of conical setae present only on body margin; rarely a few conical setae placed on dorsum A. monicae Gavrilov-Zimin \& Matile-Ferrero 


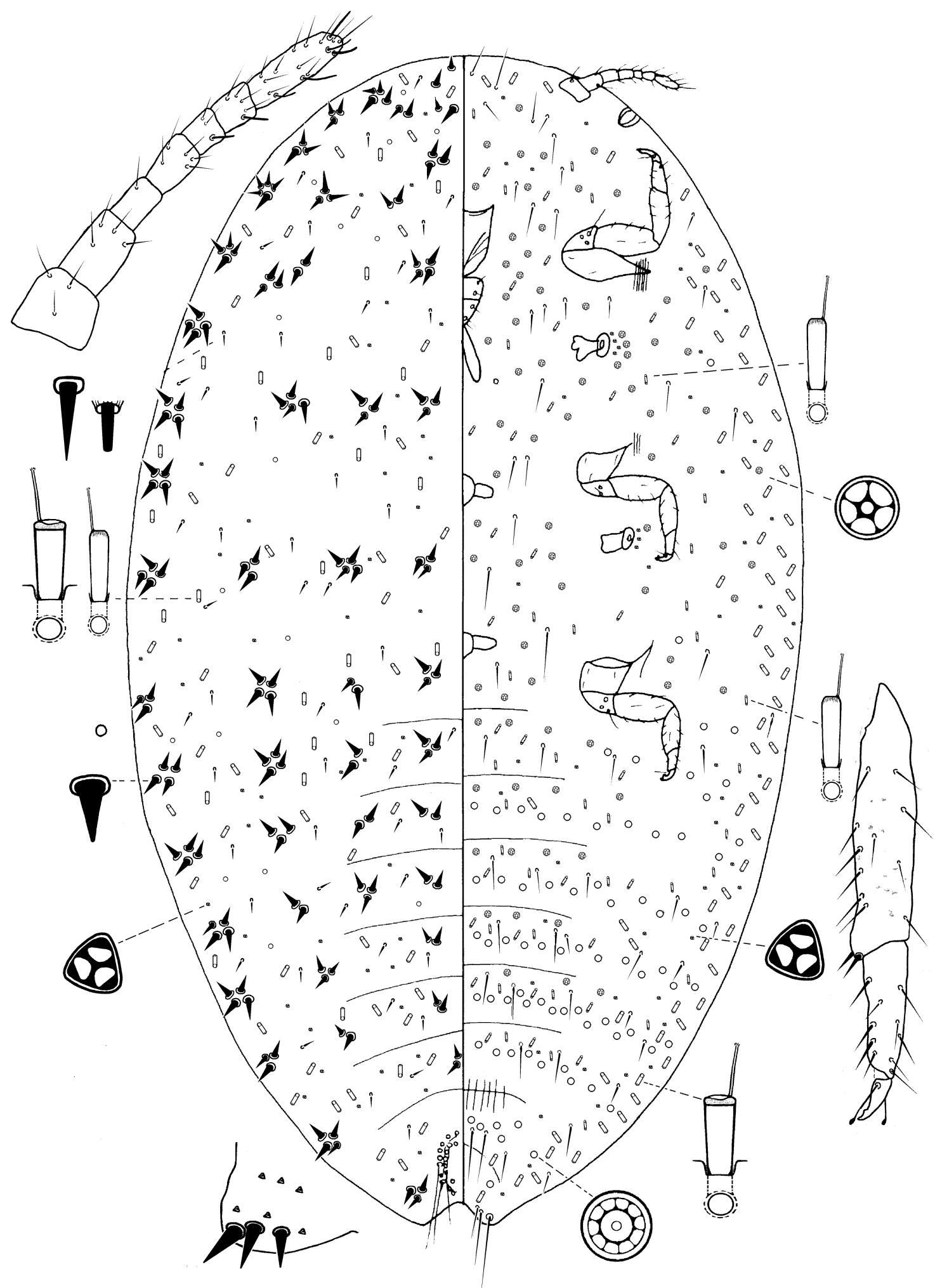

Figure 3. Artemicoccus zangherii (Kozár \& Pellizzari), paratype female. 
Two new species of Coccidohystrix Lindinger (Hemiptera: Coccomorpha: Pseudococcidae) with notes on the related genus Artemicoccus Balachowsky

\section{References}

Balachowsky, A. S., 1936. Contribution à l'étude des coccides du Nord Africain (15me note). Sur deux remarquables Pseudococcinae découverts dans le Sahara Marocain par Ch. Rungs. Bulletin de la Société Entomologique de France, 41: 157-165.

Balachowsky, A.S., 1953 a. Communications. I. Sur un Centrococcus (Coccoidea-Pseudococcini) nouveau du Maroc Oriental II. Remarques sur les Pseudococcini spinuleux. Bulletin de la Société des Sciences Naturelles du Maroc, 31: 277-285.

Balachowsky, A.S., 1953 b. Remarques complementaires sur le statut des genres Echinococcus Balachw. et Centrococcus Borkhsenius (Coccoidea-Pseudococcini). Bulletin de la Société des Sciences Naturelles du Maroc, 33: 145-147.

Ben-Dov, Y., 1994. A Systematic Catalogue of the Mealybugs of the World (Insecta: Homoptera: Coccoidea: Pseudococcidae and Putoidae) with Data on Geographical Distribution, Host Plants, Biology and Economic Importance. Intercept Limited, Andover, UK, 686 pp.

Ben-Dov, Y., D.R. Miller \& G.A.P. Gibson, 2015. ScaleNet: A Database of the Scale Insects of the World. (Web page: http://www.sel.barc.usda.gov/SCALENET/SCALENET.HTM.) (Accessed date: April 2015)

Borchsenius, N. S., 1948. Toward a revision of the genus Phenacoccus Ckll. (Insecta, Homoptera, Coccoidea). Doklady Akademii Nauk SSSR. Moscow (n.s.), 61: 953-956.

Borchsenius, N. S., 1949. Insects Homoptera. suborders mealybugs and scales (Coccoidea). Family mealybugs (Pseudococcidae). Vol. VII. Fauna SSSR. Zoologicheskii Institut Akademii Nauk SSSR. N.S., 38: 1-382.

Danzig, E.M. \& I.A. Gavrilov, 2014. Fauna of Russia and Neighbouring Countries, New series, No. 148. Palaearctic Mealybugs (Homoptera: Coccinea: Pseudococcidae). Russian Academy of Sciences, Zoological Institute, St. Petersburg, $678 \mathrm{pp}$.

Danzig, E.M., M.B. Kaydan \& I.A. Gavrilov-Zimin, 2012. A review of Palaearctic species of Artemicoccus and Coccidohistrix (Homoptera: Coccinea: Pseudococcidae). Zoosytematica Rossica, 21(2): 237-243.

Gavrilov-Zimin, I.A. \& D. Matile-Ferrero, 2014. The genus Coccidohystrix Lindinger, 1943 in the Palaeartic region with description of two new species from Maghreb (Homoptera: Coccinea: Pseudococcidae). Zoosystematica Rossica, 23(1): 96-105.

Kaydan, M.B., F. Kozár \& C. Hodgson, 2015. A review of the phylogeny of Palaearctic mealybugs (Hemiptera: Coccomorpha: Pseudococcidae). Arthropod Systematics and Phylogeny, 73 (1): 175-195.

Kosztarab, M. \& F. Kozár, 1988. Scale Insects of Central Europe. Akademiai Kiadó, Budapest, Hungary, and Dr W. Junk Publishers, Dordrecht, The Netherlands, $456 \mathrm{pp}$.

Kozár, F. \& G. Pellizzari Scaltriti, 1989. A new mealybug from Italy: Coccidohystrix zangherii sp. n. (Homoptera: Coccoidea, Pseudococcidae). Redia, 72 (2): 507-511.

Lindinger, L. 1943. Verzeichnis der Schildlaus-Gattungen, 1. Nachtrag. (Homoptera: Coccoidea). Zeitschrift der Wiener Entomologischen Gesellschaft 28: 205-265.

Marotta, S. \& A.Tranfaglia, 1994. La coccidofauna dell'Appennino abruzzese (Homoptera Coccoidea). II contributo. Bollettino del Laboratorio di Entomologia Agraria 'Filippo Silvestri', 49: 99-116.

Morrison, H. \& E.R. Morrison, 1966. An annotated list of generic names of the scale insects (Homoptera: Coccoidea). Miscellaneous Publication United States Department of Agriculture 1015: 1-206.

Neves, M., 1943. Sobre um género novo de "Kermidae" (On a new genus of "Kermidae"). Arquivos do Museu Bocage, Lisbon, 14: 1-10.

Williams, D.J., 2004. Mealybugs of Southern Asia. The Natural History Museum, Kuala Lumpur: Southdene SDN. BHD., $896 \mathrm{pp}$. 